\title{
FAKTOR PENENTU DINAMIKA PERILAKU AGRIBISNIS PETANI MANGGA DI KECAMATAN GREGED KABUPATEN CIREBON
}

\author{
Elly Rasmikayati ${ }^{1 *}$, Gema Wibawa Mukti' ${ }^{1}$, Bobby Rachmat Saefudin ${ }^{2}$ \\ ${ }^{1}$ Fakultas Pertanian, Universitas Padjadjaran \\ ${ }^{2}$ Pusat Riset Pangan Berkelanjutan DRPMI UNPAD \\ *Email: elly.agri@yahoo.co.id
}

\begin{abstract}
ABSTRAK
Cirebon sudah dikenal sebagai salah satu daerah penghasil mangga. Tetapi sampai sekarang, agribisnis mangganya belum mampu mempertahankan kualitas dan menjamin ketersediaan mangga sepanjang tahun. Permasalahan tersebut merupakan akibat dari dinamisnya perilaku agribisis yang dilakukan oleh para petaninya, sehingga pengembangan agribisnis mangga di era globalisasi harus didasarkan pada peningkatan perilaku agribisnis petani mangga ke arah yang lebih baik. Tujuan makalah ini adalah menganalisis faktor-faktor apa saja yang menentukan peningkatan perilaku agribisnis petani mangga. Metode penelitian menggunakan teknik survey di Kecamatan Greged Kabupeten Cirebon menggunakan teknik simple ramdom sampling kepada 130 petani mangga. Teknik analisis data dilakukan menggunakan path analysis. Hasil kajian menunjukkan bahwa secara berurutan dari yang terbesar ke terkecil, faktor yang paling kuat pengaruhnya secara signifikan dalam menentukan peningkatan perilaku agribisnis petani mangga adalah faktor sumberdaya dengan pengaruh langsung sebesar 5,7\% dan pengaruh tak langsung sebesar 3,5\%, faktor berikutnya adalah faktor kelembagaan dengan pengaruh langsung sebesar 6,4\% dan pengaruh tak langsung sebesar $1,8 \%$, kemudian faktor budaya dengan pengaruh langsung sebesar 5,3\% dan pengaruh tak langsung sebesar $1,7 \%$ dan terakhir faktor teknologi dengan pengaruh langsung sebesar 2,3\% dan pengaruh tak langsung sebesar $2,5 \%$.
\end{abstract}

Kata kunci: Faktor penentu, dinamika perilaku agribisnis, agribisnis mangga, path analysis

\begin{abstract}
Cirebon is already known as one of the mango-producing regions. But until now, mangosteen agribusiness has not been able to maintain quality and guarantee the availability of mangoes throughout the year. These problems are a result of the dynamic agribusiness behavior carried out by the farmers, so that the development of mango agribusiness in the era of globalization must be based on improving the agribusiness behavior of mango farmers in a better direction. The purpose of this paper is to analyze what factors determine the increase in agribusiness behavior of mango farmers. The research method used survey techniques in the Greged District of Cirebon Regency using a simple ramdom sampling technique to 130 mango farmers. Data analysis techniques are done using path analysis. The results of the study show that sequentially from the largest to the smallest, the most influential factor significantly in determining the increase in agribusiness behavior of mango farmers is the resource factor with a direct influence of $5.7 \%$ and indirect effects of $3.5 \%$, the next factor is institutional factors with a direct effect of $6.4 \%$ and indirect effects of $1.8 \%$, then cultural factors with a direct influence of $5.3 \%$ and indirect effects of $1.7 \%$ and finally technological factors with a direct effect of 2, $3 \%$ and indirect effect of $2.5 \%$.
\end{abstract}

Keywords: Determinants, dynamics of agribusiness behavior, mango agribusiness, path analysis

\section{PENDAHULUAN}

Jawa Barat sebagai salah satu wilayah andalan pengembangan mangga di Indonesia mampu memberikan kontribusi produksi tertinggi ketiga setelah Provinsi Jawa Timur dan Jawa Tengah (Tabel 1). Meskipun hanya menempati urutan ketiga di Indonesia, namun produktivitas mangga di Jawa Barat tertinggi dibandingkan keempat provinsi lainnya. Produktivitas rata-rata mangga di Jawa Barat 
dalam kurun waktu 5 tahun yakni 11,7 ton/ha sedangkan Jawa Timur dan Jawa Tengah hanya 9,5 ton/ha dan 10,3 ton/ha. Diversifikasi varietas mangga unggulan di Jawa Barat serta produksi benih tanaman mangga yang bersertifikat lebih tinggi dibandingkan Provinsi Jawa Timur dan Jawa Tengah. Lima jenis mangga utama yang dikembangkan di Jawa Barat yakni Arumanis, Gedong, Gedong Gincu, Dermayu, dan Golek (Anugrah, 2009).

Saat ini Pemerintah Provinsi Jawa Barat sedang bekerjasama dengan pemerintah Jepang di bidang perdagangan mangga Gedong Gincu dikarenakan tingginya preferensi masyarakat Jepang terhadap buah mangga asal Jawa Barat ini. Daerah penghasil mangga di Jawa Barat tersebar di 27 kabupaten dan kota. Terdapat 5 kabupaten di Jawa Barat sebagai sentra produksi mangga yang membudidayakan jenis-jenis mangga tersebut yakni Kabupaten Indramayu, Cirebon, Majalengka, Kuningan, dan Sumedang. Selain itu, produksi benih tanaman mangga yang bersertifikat di Jawa Barat lebih dari 1 juta pohon, sedangkan Jawa Timur dan Jawa Tengah hanya 178.061 pohon dan 29.601 pohon (Direktorat Jenderal Hortikultura, 2015).

Kecamatan Greged merupakan produsen mangga yang potensial di Kabupaten Cirebon (Tabel 2), meskipun jumlah pohon dan luas lahannya berada pada urutan ke-3 namun bila dilihat dari varietas dan program pengembangan komoditas mangga yang

Tabel 1.

Produksi Mangga (Ton) Menurut Provinsi Sentra di Indonesia

\begin{tabular}{|c|c|c|c|c|c|c|}
\hline \multirow[t]{2}{*}{ Provinsi } & \multicolumn{5}{|l|}{ Tahun } & \multirow{2}{*}{$\begin{array}{l}\text { Share } \\
(\%)\end{array}$} \\
\hline & 2012 & 2013 & 2014 & 2015 & 2016 & \\
\hline Jawa Timur & 840.316 & 799.410 & 922.727 & 806.644 & 655.692 & 37 \\
\hline Jawa Tengah & 422.992 & 404.443 & 459.669 & 396.636 & 334.596 & 18 \\
\hline Jawa Barat & 344.205 & 327.070 & 321.482 & 310.226 & 260.106 & 14 \\
\hline Sulawesi Selatan & 158.006 & 148.118 & 161.829 & 117.205 & 86.081 & 6 \\
\hline $\begin{array}{l}\text { Nusa Tenggara } \\
\text { Barat }\end{array}$ & 137.689 & 110.637 & 118.427 & 120.696 & 109.069 & 5 \\
\hline Jumlah & 1.903 .208 & 1.789 .678 & 1.984 .134 & 1.751 .407 & 1.445 .544 & 80 \\
\hline Indonesia & 2.376 .333 & 2.192 .928 & 2.431 .330 & 2.178 .826 & 1.814 .540 & 100 \\
\hline
\end{tabular}

Keterangan : Share : rasio antara total produksi provinsi dengan total produksi Indonesia

Sumber: Badan Pusat Statistik dan Direktorat Jenderal Hortikultura (diolah)

dilakukan oleh pemerintah pada Kecamatan Greged cenderung lebih beragam. Pada tahun 2010 luas lahan mangga Gedong gincu di Kabupaten Cirebon adalah $2.929 \mathrm{Ha}$, dari luasan tersebut ada sekitar $2 \%$ atau $50 \mathrm{Ha} 2$ yang telah terdaftar bersertifikat di Departemen Pertanian. Pendaftaran sertifikasi kebun mangga sangat penting, sebab untuk menembus pasar ekspor importir mensyaratkan buah mangga dengan asal-usul yang jelas agar bisa diketahui jaminan kualitasnya. Namun, tidak semua kebun mangga bisa didaftarkan. Selain diharuskan memiliki lahan minimal satu hektar, petani juga harus memahami dan menerapkan SOP/GAP (Hartanti 2010).

Tabel 2.

Sentra Produksi Mangga Gedong Gincu Di Kabupaten Cirebon Tahun 2015.

\begin{tabular}{|l|l|l|l|}
\hline No & Kecamatan & $\begin{array}{l}\text { Jumlah Pohon } \\
\text { (Pohon) }\end{array}$ & $\begin{array}{l}\text { Luas } \\
\text { (Ha) }\end{array}$ \\
\hline 1. & Sedong & 130.805 & 1.308 \\
\hline
\end{tabular}

\begin{tabular}{|l|l|l|l|}
\hline 2. & Dukupuntang & 82.500 & 825 \\
\hline 3. & Greged & 69.000 & 690 \\
\hline 4. & Lemahabang & 49.259 & 492 \\
\hline 5. & Astanajapura & 15.700 & 157 \\
\hline 6. & Sumber & 7.070 & 71 \\
\hline
\end{tabular}

Sumber: Dinas pertanian, perkebunan, peternakan, dan kehutanan Kabupaten Cirebon, 2015.

Pada kegiatan pemasarannya, tujuan pasar buah mangga gedong gincu ditentukan berdasarkan grade. Klasifikasi mutu (grading) hasil panen dilakukan oleh pengumpul berdasarkan ukuran, bentuk, kematangan dan kerusakan buah (Supriatna, 2010). Mangga grade $\mathrm{A} / \mathrm{B}$ (gabungan dari grade $\mathrm{A}$ dan $\mathrm{B}$ ) merupakan grade yang dipasarkan secara luas ke pasar-pasar induk luar daerah, toko/kios buah, supermarket, dan sebagian kecil sudah di ekspor. Sedangkan mangga off-grade atau grade $\mathrm{C}$ hanya disalurkan ke pasar-pasar tradisional di Kabupaten Cirebon dan sekitarnya seperti Majalengka, Sumedang, Indramayu dan Bandung (Eryani, 2009). 
Jaringan rantai pasok mangga di Kabupaten Cirebon sebagian besarnya melalui bandar. Pemasaran yang dilakukan oleh bandar adalah mangga untuk memenuhi pasar tradisional sebanyak $80-83$ persen, pasar modern 17 persen yang terbagi ke supermarket sebanyak 15 persen dan ekspor 2, sedangkan industri pengolahan masih kecil yaitu 1--3 persen (Natawidjaja dkk. 2014 dalam Sulistyowati dkk., 2015).

Persentase produksi mangga bentuk Gedong di Kabupaten Cirebon pada tahun 2010 sebanyak 60 persen, dengan grade $A / B$ sebanyak 41,9 persen dan grade $C$ sebanyak 18,1 persen, sementara bentuk Gedong gincu sebanyak 40 persen, dengan grade $A / B$ sebanyak 28 persen dan grade $C$ sebanyak 12 persen. Faktor yang mempengaruhi keputusan petani untuk memanen mangga bentuk Gedong atau Gedong gincu adalah harga pasar dan kesepakatan dengan pengumpul, apabila harga jual masih rendah petani menunda waktu panen atau menunggu harga membaik sehingga panen dilakukan dalam bentuk Gedong gincu (Supriatna, 2010).

Meskipun mangga merupakan salah satu komoditas hortikultura tropika unggulan nasional dan berpotensi memberikan peningkatan kesejahteraan keluarga petani karena memiliki nilai ekonomis yang tinggi. Namun sayangnya potensi ekonomi tersebut belum tergali karena masih banyaknya hambatan teknis maupun non-teknis yang menyebabkan produksi mangga nasional tidak stabil dan kualitasnya rendah (Sulistyowati dkk., 2013). Ketidak stabilan produksi mangga nasional dikarenakan adopsi teknologi off season di Indonesia masih rendah yaitu 17,92 \% (Sulistyowati dan Natawidjaja, 2016). Produksi mangga Gedong gincu di Kabupaten Cirebon sempat mengalami penurunan pada tahun 2010 dan 2013. Penurunan produksi mangga pada tahun 2010 disebabkan oleh terjadinya keanehan cuaca, yaitu musim hujan yang berlangsung sepanjang tahun $2010^{1}$. Cuaca ekstrem juga kembali terjadi pada tahun $2013^{2}$. Keberhasilan usaha tani mangga masih bergantung pada keadaan iklim dan cuaca, curah hujan yang tinggi menjadi faktor kegagalan produksi mangga.

\footnotetext{
${ }^{1}$ Anonim. 2011. "Panen Mangga dan Manggis Hancur.” Harian Kompas Online. Senin 10 Januari 2011. http://regional.kompas.com
}

Ketidakstabilan produksi serta rendahnya kualitas menyebabkan persentase jumlah volume ekspor mangga di Indonesia berada dibawah 0,08 persen. Padahal dengan adanya ekspor, petani dapat meningkatkan pendapatan karena harga jual mangga tujuan eskpor lebih tinggi dibanding mangga yang dipasarkan di dalam negeri. Bagi pemerintah ekspor buah mangga pun menguntungkan karena dapat menambah penghasilan devisa bagi Negara. Faktor internal yang mempengaruhi rendahnya volume ekspor yaitu terbatasnya mangga yang memenuhi kriteria kualitas ekspor, adanya pergeseran musim mengakibatkan keterlambatan atau kegagalan panen, skala usaha petani kecil, keterbatasan penerapan teknologi pascapanen mangga, kemampuan promosi eksportir, pengetahuan tentang karakteristik pasar terbatas, dan terdapat lalat buah (Purnama, 2014).

Tingginya keragaman karakteristik petani mangga dan usahataninya merefleksikan berdinamikanya perilaku agribisis mangga di Kecamatan Greged, Kabupaten Cirebon. Permasalahannya adalah bagaimana mendorong agar dinamika tersebut bergerak ke arah yang positif dan pada akhirnya dapat meningkatkan daya saing dan kesejahteraan petani mangga itu sendiri di era globalisasi yang sekarang sedang terjadi. Dengan demikian, tujuan makalah ini yaitu menganalisis faktor-faktor apa saja yang mampu mendorong para petani mangga untuk meningkatkan dinamika perilaku agribisnisnya.

\section{METODE PENELITIAN}

Penelitian dilakukan dengan metode Survey-eksplanatory, dengan pengambilan sampel Simple random sampling. Berdasarkan observasi di lapangan, diketahui jumlah kelompok tani di Kecamatan Greged sebanyak 10 kelompok dengan jumlah anggota rata-rata 18 - 23 orang per-kelompok, sehingga diperkirakan jumlah populasi petani mangga sebanyak $180-230$ orang. Berdasarkan formulasi pakar, maka ditetapkan jumlah sampel pada penelitian ini sebanyak 130 orang, karena jumlah tersebut sudah mencukupi besarnya sampel minimal untuk

\footnotetext{
${ }^{2}$ Maman. 2013. "ANOMALI CUACA: Produksi Hortikultura Anjlok 90\%”. Bisnis Online. Selasa 18 Juni 2013 http://industri.bisnis.com/
} 
penelitian kuantitatif (Suharsimi Arikunto, 2005).

Sampel petani mangga dipilih dari sampling frame didasarkan pada listing populasi petani mangga dari BPS yang diperbaharui setiap 10 tahun. BPS membagi wilayah berdasarkan sensus block yang merupakan pembagian lebih kecil dari desa/kelurahan, setiap sensus block terdiri dari 80-120 keluarga. BPS mendefinisikan petani mangga adalah keluarga petani yang memiliki 4 pohon mangga atau lebih.

Untuk menganalisis faktor-faktor yang yang menentukan peningkatan perilaku agribisnis petani mangga di kecamatan Greded kabupaten Cirebon untuk meningkatkan di era globalisasi digunakan alat analisis statistik multivariat yaitu path analysis. Variabel terikat yang dianalisis yaitu variable perilaku agribinis petani mangga, sedangkan variablevariabel bebas yang merupakan faktor yang diduga mempengaruhi perilaku agribisnis petani mangga adalah faktor sosial, faktor ekonomi, faktor teknologi, faktor sumberdaya, faktor kelembagaan dan faktor budaya. Setiap variabel diukur menggunakan beberapa indicator yang relevan dengan menggunakan skala likert. Operasionalisasi variabel-variabel tersebut tersaji dalam Tabel 3 berikut ini.

Tabel 3.

Operasionalisasi Variabel Penelitian

\begin{tabular}{|l|l|l|l|l|l|}
\hline No. & Variabel & Indikator & No. & Variabel & Indikator \\
\hline 1. & $\begin{array}{l}\text { Perilaku } \\
\text { agribisnsi } \\
\text { petani } \\
\text { mangga }\end{array}$ & $\begin{array}{l}\text { 1. Pemeliharaan pohon } \\
\text { mangga } \\
\text { 2. Penggunaan teknologi } \\
\text { 3. Perluasan lahan } \\
\text { 4. Sortasi/ grading } \\
\text { 5. Diversifikasi produksi }\end{array}$ & 5. & $\begin{array}{l}\text { Faktor } \\
\text { sumberdaya }\end{array}$ & $\begin{array}{l}\text { 1. Sarana Produksi } \\
\text { 2. Kemampuan Individu } \\
\text { Petani } \\
\text { 3. Tenaga Kerja Terampil } \\
\text { 4. Potensi Alam }\end{array}$ \\
\hline 2. & Faktor sosial & $\begin{array}{l}\text { 1. Diskusi/Sharing } \\
\text { 2. Kerjasama Petani } \\
\text { 3. Penyelesaian Konflik }\end{array}$ & 6. & $\begin{array}{l}\text { Faktor } \\
\text { Kelembagaan }\end{array}$ & $\begin{array}{l}\text { 1. Tergabung dalam } \\
\text { Kelompok Tani } \\
\text { 2. Kemitraan dalam } \\
\text { Pemasaran }\end{array}$ \\
\hline 3. & $\begin{array}{l}\text { Faktor } \\
\text { ekonomi }\end{array}$ & $\begin{array}{l}\text { 1. Akses terhadap Modal } \\
\text { 2. Permintaan Mangga } \\
\text { 3. Harga Jual Mangga } \\
\text { 3emitraan dalam } \\
\text { Permodalan }\end{array}$ \\
\hline 4. & $\begin{array}{l}\text { Faktor } \\
\text { teknologi }\end{array}$ & $\begin{array}{l}\text { 1. Teknologi Penanganan } \\
\text { Hama } \\
\text { 2. Sistem Pemupukan } \\
\text { Berkelanjutan } \\
\text { 3. Penggunaan ZPT }\end{array}$ & 7. & Faktor Budaya & $\begin{array}{l}\text { 1. Usaha Turun-Temurun } \\
\text { 2. Usaha akan } \\
\text { Diwariskan }\end{array}$ \\
\hline
\end{tabular}

Tahapan estimasi adalah membuat model ekonometrik faktor-faktor yang yang menentukan peningkatan perilaku agribisnis petani mangga di kecamatan Greded kabupaten Cirebon di era globalisasi sebagai berikut:

$$
\begin{gathered}
Y=\rho_{1} X_{1}+\rho_{2} X_{2}+\rho_{3} X_{3}+\rho_{4} X_{4}+\rho_{5} X_{5} \\
+\rho_{6} X_{6}+\varepsilon
\end{gathered}
$$

Keterangan:

$Y=$ Perilaku agribisnsi petani

$X_{1}=$ Faktor Sosial

$X_{2}=$ Faktor Ekonomi

$X_{3}=$ Faktor Teknologi

$X_{4}=$ Faktor Sumberdaya

$X_{5}=$ Faktor Kelembagaan petani

$X_{6}=$ Faktor Budaya $\rho_{i}=$ Koefisien jalur dari variabel bebas $X_{i}$

$(i=1,2, \ldots, 6)$

$\varepsilon=$ Error pengukuran

Selanjutnya, semua skala pengukuran ordinal (likert) ditransformasi menjadi skala pengukuran interval menggunakan method of successive interval agar dapat melakukan operasi aljabar yaitu menjumlahkan semua nilai-nilai dari indicator untuk menjadi nilai bagi variabelnya masing-masing. Kemudian dilakukan uji validitas, pada tahapan ini setiap indicator yang tidak valid maka tidak diikutsertakan pada pengujian selanjutnya yaitu uji reliabilitas. Pada uji reliabilitas, setiap variable yang tidak reliable maka tidak diikutsertakan pada pengujian selanjutnya yaitu uji asumsi-asumsi klasik. Kemudian setelah semua asumsi klasik terpenuhi maka 
dilakukan satu uji lagi yaitu kecocokan model atau goodness of fit test (GoF Test). Lalu setelah didapati bahwa model estimasi sudah bagus dan sesuai maka dapat dilakukan uji parsial untuk selanjutnya dilakukan interpretasi hasil estimasi dan pembahasannya.

\section{HASIL DAN PEMBAHASAN}

Analisis Validitas Data. Uji validitas atau uji kesahihan dilakukan untuk mengetahui apakah alat ukur yang telah disusun benarbenar mengukur apa yang perlu diukur. Uji validitas pada penelitian ini dilakukan dengan mengkorelasikan masing-masing pertanyaan dengan jumlah skor untuk masing-masing variabel. Teknik korelasi yang dipakai adalah teknik korelasi product moment dengan rumus (Ancok, 1989):

$$
r=\frac{n \sum P Q-\sum P \sum Q}{\sqrt{\left[n \sum P^{2}-(P)^{2}\right]\left[n \sum Q^{2}-\left(\sum Q\right)^{2}\right]}}
$$

Keterangan:

$r=$ Koefisien korelasi product moment;

$n=$ Ukuran sampel;

$X=$ Skor indikator pada variable ke- $i$;

$Y=$ skor total variable ke- $i$

Angka korelasi yang diperoleh secara statistik harus dibandingkan dengan angka kritik tabel responden. Bila $r$ hitung $>r$ tabel berarti data tersebut signifikan (valid) dan layak digunakan dalam pengujian hipotesis penelitian. Dan sebaliknya bila $r$ hitung < dari $r$ tabel berarti data tersebut tidak signifikan (tidak valid) dan tidak akan diikutsertakan dalam pengujian hipotesis penelitian.

Berdasarkan Tabel 4, didapatkan nilai Product Moment Pearson (r) dari semua indikator pada setiap variabel dinyatakan valid, sehingga semua indikator tersebut dapat diikutsertakan pada pengujian selanjutnya yaitu uji reliabilitas data.

Analisis Reliabilitas Data. Uji

reliabilitas atau uji keandalan dilakukan terhadap indikator yang sudah valid untuk menguji apakah indicator-indikator tersebut terjaga kestabilannya dalam mengungkap perilaku data. Pengujian dapat dilakukan secara eksternal maupun internal. Menurut Sugiyono dan Eri Wibowo (2004), secara eksternal pengujian dapat dilakukan dengan test retest. Sedangkan secara internal dapat diuji dengan menganalisis konsistensi butirbutir yang ada. Menurut Nunnaly (1967) dalam Ghozali (2005), suatu konstruk dikatakan reliable jika memberikan nilai Cronbach Alpha > 0,6.

Berdasarkan Tabel 5, didapatkan bahwa nilai Cronbach Alpha dari semua indikator pada setiap variabel diatas 6 sehingga dinyatakan reliabel. Dengan demikian, semua indikator tersebut dapat diikutsertakan pada pengujian selanjutnya yaitu uji asumsi klasik.

\section{Hasil Pengujian Asumsi-Asumsi Klasik 1) Uji Multikolinieritas}

Model analisis jalur yang baik hatus bebeas dari multikolinieritas atau tidak terjadi korelasi tinggi antar variabel bebas. Cara yang paling baik untuk mendeteksi ada tidaknya multikolinieritas adalah dengan melihat nilai toleransi dan Variance Inflation Factor (VIF). Apabila nilai toleransi $>0,5$ dan nilai $\mathrm{VIF}<5$, maka dapat disimpulkan bahwa tidak terjadi multikolinieritas antar variabel bebas dalam model regresi. Berikut hasil perhitungan SPSS untuk pengujian ini.

Tabel 4.

Hasil Analisis Validitas Data

\begin{tabular}{|c|c|c|c|c|}
\hline No & Variabel & Indikator & $\begin{array}{l}\text { Product Moment } \\
\text { Pearson (r) }\end{array}$ & Status \\
\hline \multirow[t]{5}{*}{1.} & \multirow{5}{*}{$\begin{array}{l}\text { Perilaku } \\
\text { agribisnsi petani } \\
\text { mangga }\end{array}$} & Pemeliharaan pohon mangga & $0,646^{* *}$ & Valid/lanjut \\
\hline & & Penggunaan teknologi & $0,613^{* *}$ & Valid/lanjut \\
\hline & & Perluasan lahan & $0,549^{* *}$ & Valid/lanjut \\
\hline & & Sortasi/ grading & $0,519^{* *}$ & Valid/lanjut \\
\hline & & Diversifikasi produksi & $0,530^{* *}$ & Valid/lanjut \\
\hline \multirow[t]{3}{*}{2.} & \multirow[t]{3}{*}{ Faktor sosial } & Diskusi/Sharing & $0,751^{* *}$ & Valid/lanjut \\
\hline & & Kerjasama Petani & $0,703^{* *}$ & Valid/lanjut \\
\hline & & Penyelesaian Konflik & $0,603^{* *}$ & Valid/lanjut \\
\hline \multirow[t]{3}{*}{3.} & \multirow[t]{3}{*}{ Faktor ekonomi } & Akses terhadap Modal & $0,667^{* *}$ & Valid/lanjut \\
\hline & & Permintaan Mangga & $0,465^{* *}$ & Valid/lanjut \\
\hline & & Harga Jual Mangga & $0,556^{* *}$ & Valid/lanjut \\
\hline
\end{tabular}




\begin{tabular}{|c|c|c|c|c|}
\hline No & Variabel & Indikator & $\begin{array}{l}\text { Product Moment } \\
\text { Pearson (r) }\end{array}$ & Status \\
\hline \multirow[t]{3}{*}{4.} & \multirow[t]{3}{*}{ Faktor teknologi } & Teknologi Penanganan Hama & $0,670^{* *}$ & Valid/lanjut \\
\hline & & Sistem Pemupukan Berkelanjutan & $0,754^{* *}$ & Valid/lanjut \\
\hline & & Penggunaan ZPT & $0,755^{* *}$ & Valid/lanjut \\
\hline \multirow[t]{4}{*}{5.} & \multirow{4}{*}{$\begin{array}{l}\text { Faktor } \\
\text { sumberdaya }\end{array}$} & Sarana Produksi & $0,564^{* *}$ & Valid/lanjut \\
\hline & & Kemampuan Individu Petani & $0,712^{* *}$ & Valid/lanjut \\
\hline & & Tenaga Kerja Terampil & $0,564^{* *}$ & Valid/lanjut \\
\hline & & Potensi Alam & $0,591^{* *}$ & Valid/lanjut \\
\hline \multirow[t]{4}{*}{6.} & \multirow{4}{*}{$\begin{array}{l}\text { Faktor } \\
\text { Kelembagaan }\end{array}$} & Tergabung dalam Kelompok Tani & $0,738^{* *}$ & Valid/lanjut \\
\hline & & Kemitraan dalam Pemasaran & $0,587^{* *}$ & Valid/lanjut \\
\hline & & Kemitraan dalam Permodalan & $0,676^{* *}$ & Valid/lanjut \\
\hline & & Dukungan Pemerintah & $0,661^{* *}$ & Valid/lanjut \\
\hline \multirow[t]{3}{*}{7.} & \multirow[t]{3}{*}{ Faktor Budaya } & Dukungan Pemerintah & $0,791^{* *}$ & Valid/lanjut \\
\hline & & Usaha Turun-Temurun & $0,690^{* *}$ & Valid/lanjut \\
\hline & & Usaha akan Diwariskan & $0,543^{* *}$ & Valid/lanjut \\
\hline
\end{tabular}

Sumber : Data Primer, diolah 2018

Tabel 5.

Hasil Analisis Reliabilitas Data

\begin{tabular}{|c|c|c|c|c|}
\hline No & Variabel & Indikator & $\begin{array}{l}\text { Product Moment } \\
\text { Pearson (r) } \\
\end{array}$ & Status \\
\hline \multirow[t]{5}{*}{1.} & \multirow{5}{*}{$\begin{array}{l}\text { Perilaku } \\
\text { agribisnsi petani } \\
\text { mangga }\end{array}$} & Pemeliharaan pohon mangga & \multirow{5}{*}{0,715} & \multirow{5}{*}{ Reliabel/lanjut } \\
\hline & & Penggunaan teknologi & & \\
\hline & & Perluasan lahan & & \\
\hline & & Sortasi/ grading & & \\
\hline & & Diversifikasi produksi & & \\
\hline \multirow[t]{3}{*}{2.} & \multirow[t]{3}{*}{ Faktor sosial } & Diskusi/Sharing & \multirow{3}{*}{0,765} & \multirow{3}{*}{ Reliabel/lanjut } \\
\hline & & Kerjasama Petani & & \\
\hline & & Penyelesaian Konflik & & \\
\hline \multirow[t]{3}{*}{3.} & \multirow[t]{3}{*}{ Faktor ekonomi } & Akses terhadap Modal & \multirow{3}{*}{0,656} & \multirow{3}{*}{ Reliabel/lanjut } \\
\hline & & Permintaan Mangga & & \\
\hline & & Harga Jual Mangga & & \\
\hline \multirow[t]{3}{*}{4.} & \multirow[t]{3}{*}{ Faktor teknologi } & Teknologi Penanganan Hama & \multirow{3}{*}{0,790} & \multirow{3}{*}{ Reliabel/lanjut } \\
\hline & & Sistem Pemupukan Berkelanjutan & & \\
\hline & & Penggunaan ZPT & & \\
\hline \multirow[t]{4}{*}{5.} & \multirow{4}{*}{$\begin{array}{l}\text { Faktor } \\
\text { sumberdaya }\end{array}$} & Sarana Produksi & \multirow{4}{*}{0,725} & \multirow{4}{*}{ Reliabel/lanjut } \\
\hline & & Kemampuan Individu Petani & & \\
\hline & & Tenaga Kerja Terampil & & \\
\hline & & Potensi Alam & & \\
\hline \multirow[t]{4}{*}{6.} & \multirow{4}{*}{$\begin{array}{l}\text { Faktor } \\
\text { Kelembagaan }\end{array}$} & Tergabung dalam Kelompok Tani & \multirow{4}{*}{0,760} & \multirow{4}{*}{ Reliabel/lanjut } \\
\hline & & Kemitraan dalam Pemasaran & & \\
\hline & & Kemitraan dalam Permodalan & & \\
\hline & & Dukungan Pemerintah & & \\
\hline \multirow[t]{3}{*}{7.} & \multirow[t]{3}{*}{ Faktor Budaya } & Dukungan Pemerintah & \multirow{3}{*}{0,760} & \multirow{3}{*}{ Reliabel/lanjut } \\
\hline & & Usaha Turun-Temurun & & \\
\hline & & Usaha akan Diwariskan & & \\
\hline
\end{tabular}

Sumber : Data Primer, diolah 2018

Tabel 6. Hasil Uji Multikolinieritas

\begin{tabular}{lll}
\hline Variabel & \multicolumn{2}{l}{ Collinearity Statistics } \\
\cline { 2 - 3 } Tolerance & VIF \\
\hline X1 & 0,595 & 1,680 \\
X2 & 0,861 & 1,161 \\
X3 & 0,664 & 1,506 \\
X4 & 0,654 & 1,530 \\
X5 & 0,629 & 1,589 \\
X6 & 0,945 & 1,058 \\
\hline
\end{tabular}

Sumber : Data Primer, diolah 2018

Berdasarkan Tabel 6 menunjukkan bahwa nilai tolerance dari masing-masing variable bebas $>0,5$ dan cenderung mendekati 1, begitu juga nilai VIF masing-masing variable bebas tidak ada yang melebihi angka 5 bahkan cenderung mendekati angka 1 . Dengan demikian dapat disimpulkan bahwa 
pada model yang dihasilkan terbebas dari multikolinieritas.

Uji Heteroskedastisitas. Uji

heteroskedastisitas bertujuan untuk menguji apakah dalam model regresi terjadi ketidaksamaan varians dari residual satu pengamatan kepengamatan yang lain. Jika varians dari residual satu pengamatan kepengamatan yang lain tetap maka disebut Homokedastisitas dan jika berbeda disebut Heteroskedastisitas. Model regresi yang baik adalah yang tidak terjadi Heteroskedastisitas. Pengujian ada tidaknya gejala heteroskedastisitas yaitu memakai metode grafik dengan melihat ada tidaknya pola tertentu pada scatterplot dari variabel terikat, dimana jika tidak terdapat pola tertentu maka tidak terjadi heteroskedastisitas dan begitu pula sebaliknya. Hasil analisis menggunakan SPSS disajikan gambar 1.

Berdasarkan Gambar 1 dapat disimpulkan bahwa pada model analisis jalur tidak memiliki gejala heteroskedastisitas karena tidak terdapat suatu pola apapun dan titik-titik tersebut tersebar secara acak dibawah dan diatas titik nol.

Uji Normalitas. Uji normalitas bertujuan untuk menguji apakah dalam model regresi, variabel terikat dan variabel bebas keduanya mempunyai distribusi normal ataukah tidak. Model regresi yang baik adalah memiliki distribusi residual normal atau mendekati normal. Uji normalitas bisa dilakukan menggunakan SPSS dengan melihat histogram dan P-P plot. Jika pada histogram nilai residual membentuk pola seperti bentuk lonceng dengan nilai tengah 0 , berarti memiliki distribusi normal. Uji normalitas menggunakan P-P Plot dikatakan berdistribusi normal jika titik-titik berada pada sepanjang garis. Hasil uji normalitas melalui histogram dan P-P Plot of Regression Standardized Residual dapat dilihat pada gambar 2 .
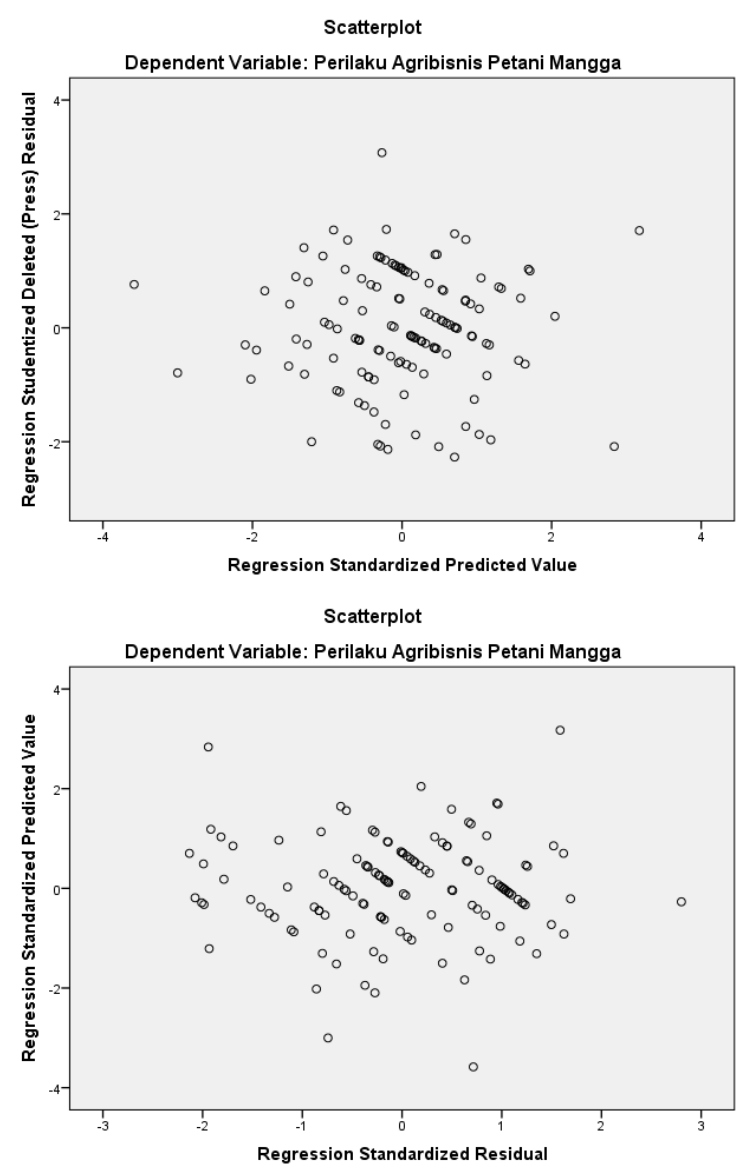

Gambar 1. Tampilan Scatterplot pada Uji Heteroskedastisitas

Sumber : Data Primer, diolah 2018

Pada Gambar 2, terlihat bahwa pada histogram polanya berbentuk mengikuti bentuk lonceng serta pada grafik normal P-P Plot titik-titik residualnya berada disepanjang garis linier (diagonal), sehingga dapat disimpulkan bahwa model analisis jalur telah memenuhi asumsi normalitas. 


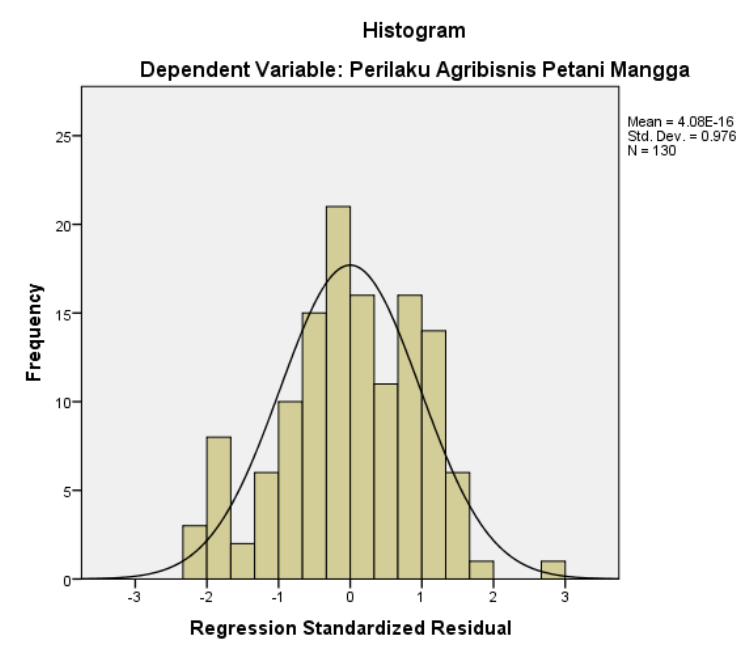

Normal P-P Plot of Regression Standardized Residual Dependent Variable: Perilaku Agribisnis Petani Mangga

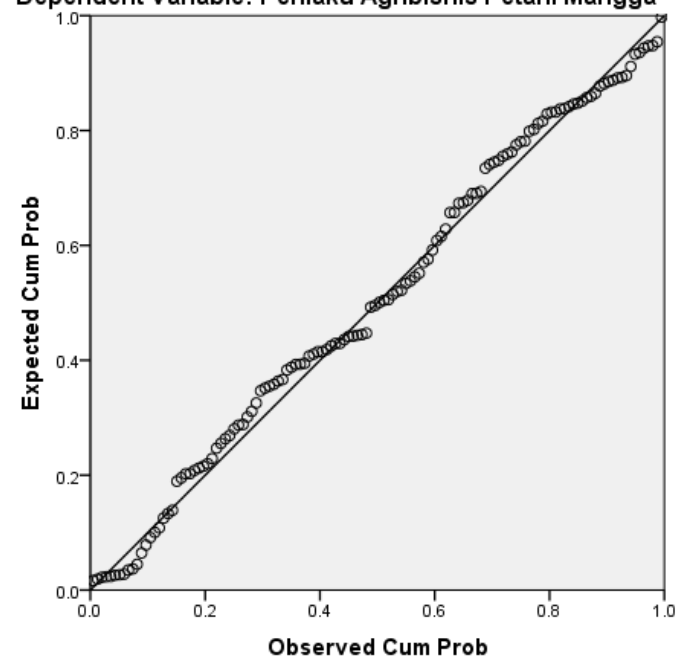

Gambar 2.

Hasil Pengujian Normalitas: Histogram (Kiri) dan Normal P-P Plot (Kanan)

Sumber : Data Primer, diolah 2018

Uji Autokorelasi. Uji atokorelasi bertujuan untuk menguji apakah dalam model regresi terdapat korelasi diantara kesalahan pengganggu dalam periode tertentu. Salah satu teknik untuk mendeteksi adanya autokorelasi adalah dengan menggunakan uji DurbinWatson (D-W) dengan kriteria sebagai berikut:

a. Jika angka D-W di bawah -2 berarti ada autokorelasi positif

b. Jika angka D-W di atas 2 berarti ada autokorelasi negatif

c. Jika angka D-W antara -2 sampai 2 berarti tidak ada autokorelasi

Berdasarkan hasil analisis didapatkan nilai D-W sebesar 1,541 sehingga dapat disimpulkan bahwa tidak terjadi autokerolasi pada model analisis jalur.

\section{Hasil Pengujian Goodness of Fit (GoF) \\ Koefisien Determinasi (R2). Koefisien}

determinasi (R2) pada intinya mengukur seberapa jauh kemampuan model dalam menerangkan variasi variabel independen. Nilai koefisien determinasi adalah antara nol dan satu. Nilai R2 yang kecil berarti kemampuan variabel-variabel independen dalam menjelaskan variasi variabel dependen sangat terbatas. Nilai yang mendekati satu berarti variabel-variabel

Berdasarkan hasil analisis didapatkan $\mathrm{R}^{2}$ sebesar 0,317 artinya variasi naik-turunnya variable perilaku agribisnis dapat dijelaskan sebanyak 31,7\% oleh ke-6 faktor/variable bebas dalam penelitian ini, sedangkan sisanya ditentukan oleh faktor-faktor lain yang tidak diteliti.

$\boldsymbol{U j i} \boldsymbol{F}$. Uji F digunakan untuk menguji hipotesis nol bahwa koefisien determinasi majemuk dalam populasi, $\mathrm{R}^{2}$, sama dengan nol. Uji signifikansi meliputi pengujian signifikansi persamaan regresi secara keseluruhan serta koefisien regresi parsial spesifik. Uji keseluruhan dapat dilakukan dengan menggunakan statistik F.

Berdasarkan hasil analisis didapatkan $\mathrm{F}$ sebesar 9,497 atau jika dikonversi ke dalam nilai peluang adalah $0,000<0,05=\alpha$ sehingga hipotesis nol ditolak dan hipotesis alternatif yang menyatakan bahwa koefisien determinasi majemuk dalam populasi, $\mathrm{R}^{2}$, tidak sama dengan nol, diterima. Dengan demikian dapat disimpulkan bahwa model analisis jalur secara simultan/keseluruhan baik (fit) secara signifikan.

\section{Hasil Analisis Faktor yang Menentukan Peningkatan Perilaku Agribisnis Petani Mangga}

Hasil estimasi model analisis jalur seperti terlihat pada Tabel 7 menunjukkan bahwa terdapat 4 faktor yang berpengaruh nyata dan positif dalam menentukan peningkatan perilaku agribisnisnya yaitu: 1) Faktor teknologi (X3); 2) Faktor sumberdaya (X4); 3) Faktor kelembagaan (X5); dan 4) Faktor budaya (X6). Sedangkan faktor sosial (X1) dan Faktor ekonomi (X2) tidak berpengaruh nyata.

Faktor teknologi (X3) berpengaruh positif dan signifikan dengan tingkat kepercayaan $90 \%$ dalam menentukan peningkatkan perilaku agribisnis petani 
mangga (Y) dengan nilai koefisien jalur sebesar 0,153. Para petani di kecamatan Greged kabupeten Cirebon sudah banyak menggunakan teknologi penanganan hama terpadu untuk mengendalikan penyakit terutama penyakit pada buah mangga. Penyemprotkan pestisida menjadi hal yang wajib dilakukan dari mulai muncul bunga hingga menjelang panen. Selain itu, petani juga menggunakan teknologi perangap lalat buah untuk mengendalikan serangan hama lalat buah. Dari segi pemeliharaan pohon mangga, petani menerapkan sistem pemupukan berkelanjutan dengan memadukan penggunaan pupuk organik dan pupuk kimia untuk mendapatkan hasil panen yang baik. Kemudian, penggunaan ZPT juga sudah banyak dilakukan para petani mangga terutama untuk mendapatkan panen diluar musim karena pada saat itu harga mangga sedang tinggi.

Tabel 7.

Koefisien Jalur serta Nilai Keberartiannya

\begin{tabular}{lllll}
\hline Variabel & Koefisien Jalur & t statistik & $\begin{array}{l}\text { Taraf } \\
\text { Nyata }\end{array}$ & Status \\
\hline Faktor sosial (X1) & $-0,019$ & $-0,199$ & 0,842 & Tidak Signifikan \\
Faktor ekonomi (X2) & 0,110 & 1,369 & 0,173 & Tidak Signifikan \\
Faktor teknologi (X3) & 0,153 & 1,672 & 0,097 & Signifikan* \\
Faktor sumberdaya (X4) & 0,239 & 2,594 & 0,011 & Signifikan** \\
Faktor kelembagaan (X5) & 0,253 & 2,693 & 0,008 & Signifikan** \\
Faktor budaya (X6) & 0,231 & 3,014 & 0,003 & Signifikan** \\
\hline
\end{tabular}

Ket: * Signifikan pada taraf nyata $10 \%$

** Signifikan pada taraf nyata 5\%

Sumber : Data Primer, diolah 2018

Faktor sumberdaya (X4) berpengaruh positif dan signifikan dengan tingkat kepercayaan $95 \%$ dalam menentukan peningkatkan perilaku agribisnis petani mangga (Y) dengan nilai koefisien jalur sebesar 0,239. Para petani mangga di kacamatan Greged sebagian besar telah memiliki sarana dan prasarana produksi yang memadai sehingga telah memiliki kemampuan untuk menghasilkan produk mangga yang banyak dan berkualitas. Selain itu, peran tenaga kerja yang terampil dan telah berpengalaman selama bertahun-tahun sangat penting dalam medukung agribisnis mangga. Dukungan kondisi alam yang sangat cocok untuk tanaman mangga di kecamatan Greged juga berpotensi untuk menghasilkan produk mangga yang banyak dan berkualitas.

Peran kelompok tani di kecamatan Greded sangat mendukung berkembangnya usahatani mangga yangdilakukan oleh petani. Kemudian dalam hal pemasaran, petani telah memiliki mitra bisnis yang dapat diandalkan untuk menjual hasil panennya. Mitra bisnis tersebut juga memberikan akses permodalan untuk keberlanjutan usahatani mangga. Dukungan dan peran dari pemerintah juga sudah cukup baik. Program-program pendidikan dan penyuluhan sudah banyak dilakukan oleh lembaga penyuluhan setempat untuk pengembangan usahatani mangga. Maka dari itu berdasarkan hasil model analisis jalur, faktor kelembagaan (X5) berpengaruh positif dan signifikan dengan tingkat kepercayaan 95\% dalam menentukan peningkatkan perilaku agribisnis petani mangga ( $\mathrm{Y}$ ) dengan nilai koefisien jalur sebesar 0,253.

Selanjutnya, Faktor budaya (X6) juga berpengaruh positif dan signifikan dengan tingkat kepercayaan $95 \%$ dalam menentukan peningkatkan perilaku agribisnis petani mangga (Y) dengan nilai koefisien jalur sebesar 0,231. Peran dan dukungan keluarga sangat mendukung dan ikut berperan dalam usahatani mangga di kecamatan Greged. Selain itu budaya bercocok tanam mangga pada petani mangga di kecamatan Greged memang sudah sejak lama dilakukan secara turun temurun dari generasike generasi. Menurut petani budaya ini akan terus diturunkan ke generasi selanjutnya dan akan tetap dijaga supaya tidak punah.

Pengaruh Langsung, Tak Langsung

dan Total. Pengaruh langsung dari suatu faktor (variable bebas) terhadap variable 
terikat adalah kekuatan faktor tersebut yang secara langsung menentukan perubahanperubahan nilai pada variable terikat. Pengaruh tak langsung adalah kekuatan suatu faktor yang secara tidak langsung menentukan perubahan-perubahan nilai pada variable terikat melalui hubungannya dengan faktorfaktor lainnya. Sedangkan pengaruh total adalah jumlah dari pengaruh langsung dan tidak langsung suatu faktor terhadap variable terikat. Jumlah pengaruh total dari semua faktor adalah nilai koefisien determinasi $\left(\mathrm{R}^{2}\right)$. Nilai-nilai pengaruh langsung, tak langsung dan total dari ke-6 faktor terhadap perilaku agribisnis petani disajikan pada Tabel 8 .

Tabel 8.

Pengaruh Langsung, Tak Langsung dan Total

\begin{tabular}{lllllll}
\hline & $\mathrm{X} 1$ & $\mathrm{X} 2$ & $\mathrm{X} 3$ & $\mathrm{X} 4$ & $\mathrm{X} 5$ & $\mathrm{X} 6$ \\
\hline $\mathrm{X} 1$ & 0,000 & 0,000 & - & 0,00 & - & 0,00 \\
& & & 0,00 & 1 & 0,00 & 0 \\
X2 & 0,000 & 0,012 & 0,00 & 0,00 & 0,00 & 0,00 \\
& & & 0 & 5 & 7 & 2 \\
$\mathrm{X} 3$ & - & 0,000 & 0,02 & 0,01 & 0,00 & 0,00 \\
& 0,001 & & 3 & 7 & 7 & 1 \\
X4 & 0,001 & 0,005 & 0,01 & 0,05 & 0,00 & 0,00 \\
& & & 7 & 7 & 3 & 9 \\
X5 & - & 0,007 & 0,00 & 0,00 & 0,06 & 0,00 \\
& 0,003 & & 7 & 3 & 4 & 4 \\
X6 & 0,000 & 0,002 & 0,00 & 0,00 & 0,00 & 0,05 \\
& & & 1 & 9 & 4 & 3 \\
\hline Pengaruh & 0,000 & 0,012 & 0,02 & 0,05 & 0,06 & 0,05 \\
langsung & & & 3 & 7 & 4 & 3 \\
\hline Pengaruh & - & 0,014 & 0,02 & 0,03 & 0,01 & 0,01 \\
tak & 0,003 & & 5 & 5 & 8 & 7 \\
langsung & & & & & & \\
\hline Pengaruh & - & 0,027 & 0,04 & 0,09 & 0,08 & 0,07 \\
total & 0,003 & & 8 & 2 & 2 & 0 \\
\hline R & 0,317 & & & & & \\
\hline
\end{tabular}

Berdasarkan Tabel 8, pengaruh langsung atau kekuatan dari faktor sosial (X1) dan faktor ekonomi (X3) yang secara langsung menentukan perubahan-perubahan dari perilaku agribisnsi petani (Y) secara berturutturut adalah sebesar 0\% dan 1,2\%. Sedangkan pengaruh tak langsung dari kedua variable tersebut yang melalui hubungannya dengan 5 faktor lainnya secara berturut-turut adalah sebesar $-0,3 \%$ dan 1,4\%. Dengan demikian, pengaruh totalnya secara berturut-turut adalah $-0,3 \%$ dan 2,7\%, namun angka-angka tersebut tidak nyata di tingkat populasi.

Pengaruh langsung atau kekuatan dari faktor-faktor yang berpengaruh nyata terhadap perilaku agribisnis petani mangga yaitu Faktor teknologi (X3), Faktor sumberdaya (X4), Faktor kelembagaan (X5) dan Faktor budaya (X6) secara berturut-turut adalah sebesar 2,3\%, 5,7\%, 6,4\% dan 5,3\% Sedangkan pengaruh tak langsung dari keempat variable tersebut yang melalui hubungannya dengan 5 faktor lainnya secara berturut-turut adalah sebesar 2,5\%, 3,5\%, 1,8\% dan 1,7\%. Dengan demikian, pengaruh totalnya secara berturutturut adalah $4,8 \%, 9,2 \%, 8,2 \%$ dan $7 \%$. Dari nilai-nilai tersebut didapatkan nilai koefisien determinasi sebesar $31,7 \%$, artinya kemampuan ke-6 faktor yang diteliti secara bersama-sama dalam menentukan variasi naikturunnya variable perilaku agribisnis petani mangga sebesar $31,7 \%$ sedangkan sisanya ditentukan oleh faktor-faktor lain yang tidak diteliti.

\section{KESIMPULAN}

Faktor yang berpengaruh nyata dan positif yang menentukan peningkatan perilaku agribisnis petani mangga di kecamatan Greged Kabupaten Cirebon adalah: 1) Faktor teknologi; 2) Faktor sumberdaya; 3) Faktor kelembagaan; dan 4) Faktor budaya. Sedangkan faktor sosial dan Faktor ekonomi tidak berpengaruh nyata. Secara berurutan dari yang terbesar ke terkecil, faktor yang paling kuat pengaruhnya dalam menentukan peningkatan perilaku agribisnis petani mangga adalah faktor sumberdaya dengan pengaruh langsung sebesar 5,7\% dan pengaruh tak langsung sebesar 3,5\%, faktor berikutnya adalah faktor kelembagaan dengan pengaruh langsung sebesar $6,4 \%$ dan pengaruh tak langsung sebesar $1,8 \%$, kemudian faktor budaya dengan pengaruh langsung sebesar 5,3\% dan pengaruh tak langsung sebesar 1,7\% dan terakhir faktor teknologi dengan pengaruh langsung sebesar $2,3 \%$ dan pengaruh tak langsung sebesar 2,5\%. Hal ini mengindikasikan bahwa untuk membangun model agribisnis mangga berkelanjutan di kecamatan Greged kabupaten Cirebon harus difokuskan pada pengoptimalan sumberdayanya, lalu peningkatan peran kelembagaannya, kemudian menjaga kelestarian budaya budidaya mangga pada para petaninya dan terakhir peningkatan penggunaan teknologi usahatani mangga. 


\section{UCAPAN TERIMA KASIH}

Terima kasih kepada Kemenristek Dikti yang telah membiayai penelitian ini dalam skema PUPT (Penelitian Unggulan Perguruan Tinggi) tahun anggaran 2017.

\section{DAFTAR PUSTAKA}

Direktorat Bina Produksi Hortikultura. 2004.

Buku Tahunan Hortikultura 2003 Seri

Tanaman Buah. Jakarta : Departemen

Pertanian, Direktorat Bina Produksi Hortikultura.

Distanbunnakhut (Dinas Pertanian Perkebunan Peternakan Kehutanan) Kabupaten Cirebon. 2010. Potensi Investasi Hortikultura (Komoditi Mangga) Kabupaten Cirebon.

Distanbunnakhut (Dinas Pertanian Perkebunan Peternakan Kehutanan) Kabupaten Cirebon 2015.

Gohong G. 1993. Tingkat Pendapatan dan Tingkat Kesejahteraan Petani serta Faktor-faktor yang Mempengaruhinya pada Daerah Opsus Simpei Karuhei di Kabupaten Kapuas Provinsi Kalimantan Tengah [Tesis]. Bogor. Program Pascasarjana IPB. 179 hal.

Mosher, A.T. 1981. Menggerakkan dan Membangun Pertanian. Jakarta: CV. Yasaguna

Pindyck, S., Robert dan Daniel L. Rubinfeld. 1998. Econometrics Models and Economic Forecast, Fourth Edition. McGraw-Hill International Edition: Singapore.

Ramadhani, W., \& Rasmikayati, E. 2017. PEMILIHAN PASAR PETANI MANGGA SERTA DINAMIKA AGRIBISNISNYA DI KECAMATAN PANYINGKIRAN KABUPATEN MAJALENGKA PROVINSI JAWA BARAT. MIMBAR AGRIBISNIS: Jurnal Pemikiran Masyarakat Ilmiah Berwawasan Agribisnis, 3(2), 185-205.

Rasmikayati, E., Sulistyowati, L., \& Saefudin, B. R. 2017. Risiko produksi dan pemasaran terhadap pendapatan petani mangga: kelompok mana yang paling berisiko. Mimbar agribisnis: Jurnal Pemikiran Masyarakat Ilmiah Berwawasan Agribisnis, 3(2), 105-116. Rasmikayati, E., Wibawa, G., Andriani, R., Fatimah, S., \& Saefudin, B. R. 2018.
KARAKTERISTIK PROSES Usahatani Dan Pemasaran Mangga Serta Potensi Dan Kendala Yang Dihadapi Petani Mangga Di Kabupaten Indramayu. Jurnal Humaniora. UNPAD.

Santosa, S. 2009. Dinamika Kelompok. Jakarta: Bumi Aksara.

Sulistyowati L, Natawidjaja R, Saidah, Z. 2013. Faktor-Faktor Sosial Ekonomi yang Mempengaruhi Keputusan Petani Mangga Terlibat Dalam Sistem Informal dengan Pedagang Pengumpul. Jurnal Sosiohumaniora. 15 (3) : 285-293.

Sulistyowati L, Natawidjaja R. 2016. Commercialization Determinant of Mango Farmers in West Java-Indonesia. IJABER Vol.11, No.11 : 7537-7557.

Sulistyowati, L., E. Rasmikayati, M.A. Budiman dan Z. Saidah. 2014. Pengembangan Kemitraan Usaha dalam Upaya Meningkatkan Komersialisasi dan Pendapatan Petani Mangga. Universitas Padjadjaran 
Vol. 3, No. 1, Juli 2018

AGRICORE:Jurnal Agribisnis dan Sosial Ekonomi Pertanian 